\title{
Entrepreneur takes charge of sinking Russian institute
}

Moscow. The Shirshov Institute of Oceanology in Moscow has appointed a successful entrepreneur as director in the hope that he can keep the renowned institute afloat in some very rough seas.

Leonid Savostin, who owns a private geological and geophysical company with annual sales of tens of millions of dollars, has recently taken over an institute that, as with nearly all Russian scientific institutions, has fallen on hard times financially. Added to its burden is the deteriorating condition of its research fleet - including the 123metre Akademik Feldysh and two deep-sea submersibles, Mir I and Mir II - and the chance that the institute may soon run out of money to operate them. For some time now the head of the submersibles programme, Anatoly Sagalevitch, has been free to strike deals with whatever organization is willing to hire the crew and pay for the fuel, but the need for ongoing maintenance and major repairs may soon force the vessels into dry dock.

The institute, run by the Russian Academy of Sciences, is no stranger to commercialism. In fact, its previous director, Vyacheslav Yastrebov, resigned last autumn after an overwhelming vote of censure. He and his colleagues were accused of mismanaging millions of rubles from exploration missions carried out by the institute's fleet that resulted in promises of payment rather than profits. A joint Soviet-French venture was said to have been put in charge of some of the institute's facilities and resources through a lease that made it almost impossible for the institute ever to regain control.

The replacement of Yastrebov, a robotics engineer, by Savostin, a geologist, surprised many at the institute. "We regard his appointment as our victory", says one researcher, "but the choice that we've made is so unusual that we still harbour some doubts."

Five years ago, Savostin left the institute to found his own Laboratory of Regional Geodynamics (LARGE). He received a contract from the institute for exploration and used it as collateral to buy a fishing boat and convert it into a research vessel. With it he competed successfully for Western contracts involving underwater search and exploration missions. He was also granted several concessions to search for gold in the waters off South Africa.
Savostin says that he decided to apply for the post of director because "I realized that the institute needed a man with my experience and opportunities". Although some were concerned that he would siphon off

\section{IMAGE UNAVAILABLE FOR COPYRIGHT REASONS}

likely that the money will flow in the opposite direction. The institute has already received large dividends from depositing some of its money with the company over the Christmas holidays.

Savostin says that he has not been in the job long enough to have formulated detailed plans on ways to rescue the institute, which some fear may not be able to stay open beyond the end of the year. One possibility that he has broached is an international research programme that would make use of the institute's chief asset - its fleet. The institute's good repu-

institute funds for his own ventures, and even proposed unsuccessfully that the academy change its rules to prohibit any representative of a private company from serving as director of an institute, it seems more tation in the West, he says, "is capital that is somehow underestimated in Russia", he says, and it is the duty of the director to make that asset pay off.

Vladimir Pokrovsky

\section{Foundation begins competition for survival grants to Russians}

Moscow. Competition has begun for the first round of survival grants to scientists in the former Soviet Union (FSU), part of a pledge of $\$ 100$ million from US financier George Soros to support science in the region (see Nature 360, 617; 1992).

The International Science Foundation, based in New York, plans this spring to give $\$ 500$ to between 10,000 and 20,000 scientists who have published at least three papers during the past five years in recognized journals. The most deserving scientists will also receive as much as $\$ 1,000$ to be divided among their research team. In addition, the foundation is making available $\$ 1$ million for FSU scientists to attend scientific conferences abroad. Applicants must submit material by 31 March to be eligible for the first round of awards. The second and final deadline is 31 May.

As many as 30,000 scientists, who must be active in an area of basic science, are expected to apply for the grants. The applications will be divided into three categories according to the impact of the work as measured by citation analysis. The top group will receive individual and group grants to keep research teams intact and the middle group only individual grants; the bottom group will be reexamined using other criteria, and some percentage will be funded.
Institutions with the greatest concentration of grant recipients will also be eligible for grants to support telecommunications and other infrastructure needs. The foundation is also developing a programme to help FSU libraries that are no longer receiving important scientific journals.

The selection format, designed to provide as much support as possible as quickly as possible to the greatest number of scientists, is not without controversy. Representatives from the Baltic states lobbied unsuccessfully for a quota system to provide for geographical distribution, if not for a separate foundation. Members of the US advisory board disagreed with their Russian colleagues about the criteria for the awards, with US scientists arguing for applicants to submit proposals that would be judged on the basis of scientific merit and Russian scientists emphasizing the need to disseminate funds as quickly as possible.

Foundation officials admit that their efforts are "a great experiment" and they acknowledge criticism that such an injection of funds could undermine the existing system of supporting research. But they are confident that the money will be well-spent and that the experiment, despite facing formidable logistical problems, "is bound to be a success".

Vladimir Pokrovsky 